UDC: 377

DOI: https://doi.org/10.24195/2414-4665-2017-6-9

\author{
Hanna Kashyna, \\ PhD (Candidate of Pedagogical Sciences), \\ National Pedagogical Dragomanov University, \\ 9, Pyrohova Str., Kyiv, Ukraine \\ Vira Lebedeva, \\ Doctor of economics, associate professor, \\ Department of Administrative Management and Market Problems, \\ Odessa National Polytechnic University, \\ 1, Shevchenko Avenue, Odessa, Ukraine \\ Maryna Kashtalian, \\ PhD in Medicine, associate professor, \\ Department of Obstetrics and Gynaecology No1, \\ Odessa National Medical University \\ 2, Valikhovsky lane, Odessa, Ukraine
}

\title{
SIMULATION TEACHING TECHNOLOGY IN MODERN EDUCATIONAL SYSTEM REFORMATION
}

Modern education aims to form an all-round future professional. So only semiotic means of training are not enough, the necessary technologies should be based on the principle of "perceiving through performing" involving effective professional tests, manifesting themselves in the development of professional competence, providing the designing of situations and appropriate situational reflection. This studying should result in not narrow knowledge in a certain sphere, but versatile one with the possibility of its further adaptation to a changing context. The article deals with the expediency of implementing a simulation teaching technology in terms of training and simulation company, the features of its adaptation to the Ukrainian educational system, the combination of methods and technologies applied in terms training and simulation company. It has been concluded that this technology has a positive impact of the development of modern professionals.

Keywords: education, educational technology, educational and training company, simulation teaching technology, educational reform.

\section{Introduction}

In terms of restructuring the industrial society into the information one there have been increasing the requirements to professionals, whose main value orientations, except for those defined in the process of professional training, are the ability to make a rational use of time, applying information and communication technologies, apart from performing certain instructions algorithms, the ability to offer employers alternatives based on their own analysis forecasts to deal with corporate tasks; a high level of self-reflection, stable motivation to selfeducation with the view to integrate the functions of related positions without using outdated and ineffective method of personnel changes. All the above listed factors have greatly influenced the modernization of Ukrainian education, the issue of specific professional orientation in high school, fostering in the graduates the adaptability to new market requirements, the ability to change the scope and ways of activities effectively, be objectively engaged into new educational, professional, socio-cultural and international environment. In full extent these tasks can be solved by a simulation teaching technology that allows to go beyond the theoretical studying and correlate it with future work to reflect the practical knowledge in solving occupational problems. Among modern didactic concepts involving the simulation of different kinds of professional activities the technology of training and simulation companies is the most desirable one.

Modeling in education, namely in institution's management has been researched by V. Bespalko, A. Dahin, I. Yermakov, I. Konovalchuk G. Kravchenko, A. Kuklin, N. Pryhodkina, S. Ryabova, T. Sushchenko, N. Yakovlev and others. The issue of establishing conceptual foundations of life creativity are reflected in the works of such local and foreign scientists as S. Amonashvili, W. Doniy, I. Yermakov, V. Lizynskiy, V. Palamarchuk G. Sagach, A. Khutorsky A. and others. The success in life is formed on the grounds of creative work, which refers to the spiritual practice of a personality aimed at design, planning, programming and creative realization of life journey. We share the opinion of I. Yermakov, who believes that it is the institution's administration members who determine the dominants and quality characteristics of the "school" of life competence: the development and self-fulfillment of students as the subjects of culture, the creators and designers of their lives. The personality acts in this process as a developed individual, a subject of individual life, and the object of his/her individual creative acts is his/her life [1]. 
The results of the scientific literature review on management of educational institution's development on the basis of modern educational technologies allow to admit that the issue is not fully investigated in both theoretical and practical aspects.

The article aims to research theoretical aspects and give practical recommendations concerning the adaptation of the simulation teaching technology to the modern education system in terms of a training and simulation company.

\section{The following task are going to be fulfilled:}

- to reveal the peculiarities of the simulation teaching technology in terms of a training and simulation company;

- to propose a system of criteria and indicators of the professional growth of a personality;

- to analyze the existing model of the training and simulation companies.

\section{Discussion}

The labor market of postindustrial, information society, which is characterized by the struggle for the efficiency and ultra-high competition, and the content of activity is associated in most cases with the creation, storage, processing and realization of information, is marked by sectoral division, joint resources, the universalization without distinguishing material and intellectual kinds of production. Therefore, a trait profile of a specialist is changing, as well as his/her professional model.

In modern HR-management shaping the positions and creating theoretical models of specialists (including personal) is considered to be an effective tool for evaluating the level of the formation of professionally important qualities and at the same time a selection criterion for filling vacancies without wasting time for interviewing.

The model of a specialist's professional development is one of the factors adjusting the educational content and the forms of its implementation, which helps focus the educational process on its final result, basing on specific requests of relevant professional fields. However, according to the latest trends in the labor market, an old qualification model of a professional popular in the Soviet system is replaced by a competence model, which provides the mobility of specialists in changing employment conditions, makes focus on the development of professionally important qualities and their interrelations at the level required by mastering related professions or professional fields.

At present there is no doubt that the competence approach is one of the factors contributing to the modernization of education. It complements a series of educational innovations and classical approaches that help educators combine harmoniously positive experience for the implementation of advanced educational purposes. Under these conditions a teacher not only performs cognitive functions but also promotes the development of both professional and communicative, aesthetic, spiritual, moral and creative qualities of future specialists.
Thus, the image of a highly-competitive specialist of the $21^{\text {st }}$ century (without specifying the sector of industry and detailed profiling of individual positions) is associated with such concepts as professional competence, professionalism, professional universalism. Since all these concepts are united by the common condition of formation - active practice, professional self-testing, then the simulation teaching technology in terms of a training and simulation company (TSC) under conditions of successful interdisciplinary integration of theory and practice creates the most favorable environment for the formation of a specialist [2].

The Ukrainian version of TSC is a complex of modern educational technologies that do not only simulate the real work of a company, but also aim to develop professionally important qualities of students, build key competencies, facilitate a phased system of vocational work, professional development and integration of a student into the labor environment. Based on the experience of TSC functioning at educational institutions of different accreditation levels of vocational, secondary (with the right for vocational training) and higher education such methods and technologies as the project method, the portfolio method and the modular teaching technology should be singled out as they give positive results and are peculiar for TSC activity.

Projecting is a special type of intellectual activity, whose distinctive feature is a promising orientation, practically directed research, that is why the method of projects is widely utilized in the conditions of TSC [3].

The project method is focused primarily not on the integration of actual knowledge, but its use and acquisition of the new one (often by means of self-study), whereby the understanding of independently gained information is performed through the prism of personal attitude towards it and the evaluation of the final result. The active involvement of students in various projects provides an opportunity to master new ways of activity in socio-cultural or socio-economic environment. Special attention in the socio-economic environment should be paid to the capitalization of brands in the context of increasing the value of business and its competitiveness [45].

Taking it into account, it can be summarized that the project method involves all the stages that are important for occupation-related, simulation studies, namely, informational, organizational and practical, reflective, and correctional. Thus, the application of the project method in terms of TSC creates the environment for students' self-realization, increases motivation for gaining knowledge, contributes to the development of their intellectual abilities, getting experience of solving real problems in view of the future independent life, which are projected in the study.

Just like the structure of a going concern is formed in accordance with the needs of the local market, the nature of products, working facilities, technological processes, financial capabilities, relations with partners and competi- 
tors, other economic and social factors, the structure of a training and simulation company besides of modeling the above mentioned aspects must take into account the specificity of the institution, its educational needs and the needs of the students, as well as a regional component.

The following example of work of Stepanivka interschool training and production center of Chernihiv region highlights the possibility of creating TSC on the basis of the institution of general secondary education, which is a resource center of educational school districts, taking into account all trends of profilization represented in regional areas.

The interschool work training center is an educational institution that meets the requirements of high school students in vocational training for working trades together with the acquisition of secondary education and also performs pre-profile training, promotes quality and profile training and provides vocational guidance, including preuniversity training.

The structure of TSC "Kombinat" ("Amalgamation") makes it possible to study according to the rotating system where students move from post to post with the aim of the practical introduction to the profession, the implementation of multi-level tasks, writing projects, taking tests. And at the same time it offers everything necessary for industrial training according to vocational occupations in the work training center.
In addition, TSC "Kombinat" has a hierarchical structure of relations which helps students to adaptat to new standards of labor. In particular, the following categories are distinguished: first-line managers (operational control) and the relevant departments of their competence and organization; mid- and top level managers (Fig. 1).

In the process of rotation of the TSC staff, each student has an opportunity to make a professional test in the field chosen together with a psychologist and career adviser. The practical tasks are selected out of any of the modular units according to career tasks under requests, capacities and abilities of the students. This can be the fragmented imitation of occupational work with the development of individual educational plans or a systematic study of a certain aspect of work with its final assessment and even a further assignment of a qualification. The practical tasks are supplemented by seminars, master classes, and business games.

The most proactive students who intern at TSC or perform practical tasks within vocational training, develop projects as a result of their work. It is a thorough study of the labor and industrial phenomenon from the point of self-analysis of information that is not a part of the curriculum. This approach encourages the students' interest in the national education system and, in its turn, helps to solve the migration problems in the country [6].

Top Management

$\mathrm{CEO}, \mathrm{CFO}$, sales director, marketing director, executive director, director of public relations, director of the advertising department, personnel manager, director of regional development and their deputies.

Specific demands: the formation of goals and the development of strategies, flexibility in decisionmaking, forecasting ability based on professional experience, the ability for innovative activities, adaptation to changes, the ability to build complex plans, projects of development, cooperation and integration.

\section{Middle management}

Heads of workshops, laboratories, departments; functional leaders involved into coordination of work of primary leaders, preparing the necessary information for top management, presenting decisions of senior management in a convenient, comprehensive way to younger leaders (in the form of specific tasks), analyzing industrial and economic performance, promoting the development of new ideas.

Specific requirements: mastering different methods of analysis using computer facilities, knowledge of scientific methods of management and decision-making, methods in the sphere of management psychology, the ability to motivate work.

\section{Down-management}

Masters, senior craftsmen, leaders of small groups, younger leaders engaged in distribution of tasks, monitoring the progress of their implementation, monitoring the rational use of resources. The nature of work is the frequent change of tasks (operative work), they have more contacts with the performers than the authorities.

The performers are divided into "the white collars" - engineering and technical personnel and clerical employees, and "the blue collars" - workers engaged in the manual labor.

Specific requirements: the ability to relieve the stress after the decisions of senior management, the ability to prevent conflicts, the rational distribution of tasks, etc.

Fig. 1. The hierarchy structure in the TSC "Kombinat" 
The stage of carrying out practical tasks and working on projects is the most valuable aspect of acquiring skills, the formation of life and professional competence, mobility, universalism, building a career path and developing life position. Due to it the freedom of intellectual activity can be achieved, critical thinking skills and the ability to solve problematic situations are consolidated that promotes the development of such important features as stress resistance, the endurance to frustration, adaptability, the ability to tackle diverse tasks without negative psychological effects (Table. 1).

The system of criteria and indicators for the professional growth of an individual at TSC

\begin{tabular}{|c|c|c|}
\hline Criteria & Indices & Expected results \\
\hline $\begin{array}{l}\text { Formation of profes- } \\
\text { sional position }\end{array}$ & $\begin{array}{l}\text { - social significance of selected profes- } \\
\text { sion during training at TSC; } \\
\text { - the complex of formed professionally } \\
\text { important qualities; } \\
\text { - professional competence; } \\
\text { - readiness for work }\end{array}$ & $\begin{array}{l}\text { The completeness of ideas about the chosen } \\
\text { profession, understanding the conditions and } \\
\text { factors for effective education, training and pro- } \\
\text { fessional growth. }\end{array}$ \\
\hline $\begin{array}{l}\text { Development of entre- } \\
\text { preneurial competen- } \\
\text { cies }\end{array}$ & $\begin{array}{l}\text { - inventiveness; } \\
\text { - creativeness; } \\
\text { - willingness to take risks; } \\
\text { - motivation for success; } \\
\text { - the ability to plan; } \\
\text { - the ability to manage projects } \\
\end{array}$ & $\begin{array}{l}\text { Being focused on achieving business results. The } \\
\text { implementation of technical, social, artistic and } \\
\text { economic projects. }\end{array}$ \\
\hline $\begin{array}{l}\text { Desire for social and } \\
\text { professional autonomy }\end{array}$ & $\begin{array}{l}\text { - autonomy; } \\
\text { - initiativeness; } \\
\text { - responsibility; } \\
\text { - creativity }\end{array}$ & $\begin{array}{l}\text { The capacity for constant self-education and } \\
\text { self-development during the life time }\end{array}$ \\
\hline $\begin{array}{l}\text { Acquisition of related } \\
\text { professional compe- } \\
\text { tences }\end{array}$ & $\begin{array}{l}\text { - expanding vocational skills; } \\
\text { - the possibility of combining profes- } \\
\text { sions; } \\
\text { - the work on interdisciplinary projects }\end{array}$ & $\begin{array}{l}\text { The construction of a strategic way of profes- } \\
\text { sional development and the growth through the } \\
\text { extensive vocational skills, the acquisition of } \\
\text { related professional competences }\end{array}$ \\
\hline $\begin{array}{l}\text { Future specialists' } \\
\text { focus on professional } \\
\text { fulfillment }\end{array}$ & $\begin{array}{l}\text { The construction of a career plan, devel- } \\
\text { oping a system of clear objectives, } \\
\text { methods and steps of achieving profes- } \\
\text { sional intentions }\end{array}$ & $\begin{array}{l}\text { Determining the level of one's own ambitions } \\
\text { and capabilities based on testing and internship } \\
\text { results }\end{array}$ \\
\hline
\end{tabular}

As a result, the students are prepared for a successful integration into real working teams, bring actual profit to an educational institution where they are trained through the execution of the tasks within industrial practice associated with the creation of material goods; become competitive at a regional labor market [7] (provided that the TSC is established taking into account the economic needs and the specific features of a region), are aware of where and how this knowledge can be used in real life, studying corporate culture, develop skills of constructive corporate engagement, acquire basic professional skills, including multipurpose ones, such as records keeping, writing business plans, the organization of marketing research or advertising campaign [8].

\section{Conclusions}

Therefore, we consider the adaptation of the simulation technology of training in terms of TSC to the realities of Ukrainian education as an effective means of modernization and improvement of the national education system,

\section{REFERENCES}

1. Ermakov, A. I. (2006). Kompetentnisniy potentsial proektnoi diialnosti [Competency potential project as in the process of its implementation educational process participants' talents are taken into account, as well as industry orientation, which is characterized by the staff shortage. During industrial training organized in this way such features as creative activity, independence, professional attitude, competence and professional universalism of future specialists are formed. The described experience shows that the following tasks of the new-type educational process organization are considered to be the most urgent and problematic: a change of attitude towards the content of education as the synthesis of self-study and self-organization; increasing students' motivation by means of creating conditions for their self-realization (which is impossible in a closed educational space without the consolidation of efforts of various organizations, institutions and enterprises); providing the innovative educational system in financial, technical, legal and psycho-pedagogical aspects; training and involving the teaching staff of a new type.

activities]. Shkola dlya zastupnikiv $i$ ne tilki - School for deputies and more, 5, 5-11 [in Ukrainian]. 
2. Ivanyuk, I. V. (2006). Osvitnya politika [Education policy]. Kyiv: Takson [in Ukrainian].

3. Kuklin, O. V. (2001). Organizatsiya pidgotovki fakhivtsiv iz komertsiynoi diialnosti [Organization of training specialists in business]. Lviv: Oriyana-Nova [in Ukrainian].

4. Gryshova, I. Yu., \& Shabatura, T. S., \& Naumov, O. B. (2016). Kapitalizatsiia brendu yak instrument maksymizatsii rynkovoi vartosti biznesu [The capitalization of the brand as a tool for maximizing business value]. Naukoviy visnik Polissya - Scientific bulletin of Polissia, 3(6), 168-175 [in Ukrainian].

5. Gryshova, I., \& Mityay, O., \& Stoyanova-Koval, S. (2016). The estimation of enterprise trade name com-

\section{ЛІТЕРАТУРА}

1. Єрмаков I. Є. Компетентнісний потенціал проектної діяльності / І. Є. Срмаков // Школа для заступників і не тільки. - 2006. - №5. - С. 5-11.

2. Іванюк І.В. Освітня політика: навч. посіб. / I.В. Іванюк. - К.: Таксон, 2006. - 225 с.

3. Куклін О.В. Організація підготовки фахівців із комерційної діяльності / О.В. Куклін. - Львів: ОріянаНова, 2001. - 220 c.

4. Гришова І.Ю. Капіталізація бренду як інструмент максимізації ринкової вартості бізнесу / І.Ю. Гришова, Т.С.Шабатура, О.Б. Наумов // Науковий вісник Полісся. - №3(6). 2016. - С. 168-175.

5. Gryshova I.Yu. The estimation of enterprise trade name competitiveness / I.Gryshova, O.Mityay, petitiveness. Naukoviy visnik Polissya - Scientific bulletin of Polissia, 2(6), 85-91 [in Ukrainian].

6. Gryshova, I. Yu., \& Strielkowski, W. (2016). Ukrainian labour migration in the Czech Republic. Scientific bulletin of Polissia, 3 (8), 224-231 [in Ukrainian].

7. Shestakovska, T. L., \& Savchenko, V. F. (2016). Osoblyvosti formuvannja socialno orijentovanyh klasteriv $\mathrm{v}$ Ukraini [Features of formation of socially oriented clusters in Ukraine]. Naukovyi visnyk Polissia-Scientific bulletin of Polissia, 1, 46-55 [in Ukrainian].

8. Gryshova, I. Yu., Zamlynskyi, V. A., Shestakovska, T. L. (2017). Implementing Cluster Forms Into National Education Development Strategy. Nauka i osvita - Science and education, 5, 56-61 [in English].

S.Stoyanova-Koval // Scientific bulletin of Polissia. №2(6). - 2016. - C 85-91.

6. Gryshova I.Yu. Ukrainian labour migration in the Czech Republic / Wadim Strielkowski, I. Yu. Gryshova // Scientific bulletin of Polissia. - 2016. - №4(8). - C.224-231.

7. Шестаковська Т.Л. Особливості формування соціально оріснтованих кластерів в Україні / В.Ф. Савченко, Т.Л. Шестаковська // Науковий вісник Полісся. - 2016. - №1. - С.46-55.

8. Gryshova I.Yu., Zamlynskyi V.A., Shestakovska T. L. Implementing Cluster Forms Into National Education Development Strategy / I.Yu. Gryshova, V.A. Zamlynskyi, T. L. Shestakovska // Наука і освіта. - 2017. №5. - C. 56-61.

Ганна Сергї̈вна Кашина, кандидат педагогічних наук, дочент кафедри освіти дорослих, Національний педагогічний університет імені М. П. Драгоманова, вул. Пирогова, 9, м. Київ, Украӥна,

Віра Василівна Лебедєва, доктор економічних наук, доцент кафедри адміністративного менеджменту та проблем ринку, Одеський національний політехнічний університет, пров. Шевченка, 1, м. Одеса, Украӥна

Марина Михайлівна Каштальян, доктор медичних наук, доиент кафедри акушерства та гінекології №1, Одеський національний медичнийо університет, пров. Валіховського, 2, м. Одеса, Украӥна

\section{АКТИВІЗАЦІЯ ІМІТАЦІЙНОЇ ТЕХНОЛОГІЇ НАВЧАННЯ У НАПРЯМКУ РЕФОРМУВАННЯ СУЧАСНОЇ СИСТЕМИ ОСВІТИ}

Метою сучасної освіти стає формування моделі цілісного образу майбутнього професіонала. Тому самих лише семіотичних засобів навчання недостатньо, необхідні технології, що грунтуються на принципі «виконуючи пізнаю», тобто передбачають дієві професійні проби, реалізуються через професійно-трудову компетенцію, мають діяльнісний зміст, передбачають конструювання ситуацій та відповідну ситуативну рефлексію. Результатом такого навчання мають стати не вузькоспеціалізовані знання, а універсальні - $з$ можливістю їх подальшої адаптації до мінливого контексту. У статті обгрунтовано доцільність упровадження імітаційної технології навчання в умовах навчально-тренувальної фірми, розглянуто особливості її адаптації до української системи освіти, проаналізовано сукупність методів і технологій, що застосовуються в умовах навчально-тренувальної фірми, прослідковано вплив цієї технології на формування особистості сучасного фахівця. Адаптація імітаційної технології навчання в умовах НТФ до реалій української освіти розглядається у дослідженні як дієвий засіб модернізації і оновлення вітчизняної освітньої системи, оскільки при іiі запровадженні враховуються індивідуальні професійні здібності учасників навчального процесу, галузева направленість, де спостерігається дефіцит кадрів, а у процесі організованого таким 
чином виробничого навчання формуються творча активність, самостійність, чітка професійна позиція, компетентність та професійний універсалізм майбутнього спеціаліста. Найбільш важливими і досі проблемними лишаються такі задачі організації освітнього процесу нового типу: зміна ставлення до змісту освіти як до синтезу самоосвіти, самоорганізації та самовиховання; зміна мотивації суб'єктів освітнього процесу шляхом створення умов для їхньої самореалізації (що неможливо у закритому освітньому просторі без консолідації зусиль різних організацій, установ, підприємств); забезпечення інноваційної освітньої системи в фінансовому, матеріально-технічному, юридичному та психолого-педагогічному плані; підготовка і залучення педагогічних кадрів нового типу.

Ключові слова: система освіти, освітні технології, навчально-тренувальна фірма, імітаційна технологія навчання, реформування освіти.

Submitted on May, 22, 2017

UDC: $378.147: 004.4: 5$

DOI: https://doi.org/10.24195/2414-4665-2017-6-10

Ihor Puchkov,

ces), associate professor,

Vladyslav Sariienko,

PhD (Candidate of Pedagogical Sciences), associate professor,

Volodymyr Sariienko,

PhD (Candidate of Pedagogical Sciences), associate professor, Department of Science Disciplines and Mathematics, Donbas State Pedagogical University, 19, H. Batiuka, Sloviansk, Ukraine,

\section{DIDACTIC FOUNDATIONS OF SOFTWARE STRUCTURING IN THE PROCESS OF TEACHING SCIENCE DISCIPLINES AND MATHEMATICS AT PEDAGOGICAL UNIVERSITIES}

Science disciplines and Mathematics are considered to be a fundamental evidential and technical base of modern researches and production; they contribute to the formation of scientific worldview, intellectual development, provide acquisition of knowledge and skills necessary for working with a PC. When developing the technology of structuring software for teaching science disciplines and Mathematics at pedagogical universities one should regard that it must cover all structural components of the educational process (target, motivational, content, operative and regulative, as well as estimation and result). The relevance of the research is explained by the necessity of determining didactic foundations of software structuring in the process of teaching scientific disciplines and Mathematics, as it affects the level of future teachers' professional competence. The paper aims to prove the necessity of software structuring as a way of achieving the optimal combination of different program teaching methods which provides the development of students' self-study skills in the process of mastering scientific disciplines and Mathematics. The has been conducted the pedagogical experiment aimed at checking the efficiency of the developed technique of structuring the software for teaching science disciplines and Mathematics at the Department of Physics and Mathematics of Donbas State Pedagogical University involving $1202^{\text {nd }}-5^{\text {th }}$ year students divided into control and experimental groups. The checking was carried our according to the following criteria: motivational; cognitive; vocational. Pearson's chi-squared test $(\chi 2)$ was used for the research outcomes verification. The carried out pedagogical experiment has proved the expediency of the developed technology of software structuring in the process of teaching scientific disciplines and Mathematics, which provides the increase of the level of students' professional competence.

Keywords: pedagogical experiment, software, structuring, teaching, science disciplines, mathematics, professional competence.

\section{Introduction}

One of the priority areas of modern higher pedagogical education development is active implementation of various computer technologies into the educational process, which significantly improve the quality of training. Their application involves reinterpretation of the basic structural components of teaching and learning: goals, content, methods, organizational forms, evaluation crite- ria, and correction of the obtained results if necessary. In view of this, the need for the development of modern software for teaching students in general, and determination of didactic foundations of its structuring in particular, are of great importance [6], [7].

In the process of training future teachers special attention is paid to science disciplines and Mathematics because they are regarded as a fundamental evidential and 